\title{
Structure and comparative anatomy of the toothplate in the Buliminacea (Foraminiferida)
}

\author{
STEFAN A. REVETS \\ Koninklijk Belgisch Instituut voor Natuurwetenschappen, Department of Palaeontology, \\ Vautierstraat 29, B1040 Brussels, Belgium.
}

\begin{abstract}
The toothplate is an important element of the apertural complex in the Buliminacea. Structurally speaking, it is a plate of inner lining, drawn out from under the apertural wall which descends into the lumen to contact the foramen. All the other apertural elements are bilamellar.

The degree of morphological complexity of the toothplate varies with the taxon; this has consequences for the taxonomy of the group. The diversity of the toothplate morphology in Bulimina might be used to divide the genus. Buliminella has to be revised since it seems to contain at least three separate entities, one of which does not belong to the Buliminacea. Praeglobobulimina is distinct from Globobulimina, the latter having lost the toothplate. Buliminellita and Turrilina are close relatives of Buliminella. Buliminoides has to be removed from the Buliminacea, and should be considered incertae familiae. Praebulimina possesses the simplest toothplate of the taxa investigated.
\end{abstract}

\section{INTRODUCTION}

One of the characteristic features of the Buliminacea is the toothplate, usually described as a protrusion in the apertural opening, which descends into the chamber lumen, and connects the foramen with the aperture. From the very beginning, authors described the presence of a 'tooth' in the aperture of Bulimina. Surprisingly, this feature was not used for taxonomical purposes. It was not until the thorough studies by Höglund (1947) and Hofker (1951), that the toothplate became an important element in the systematics of the buliminids.

Höglund (1947) made a detailed study of the toothplate in Globobulimina auriculata and to a lesser extent in Bulimina marginata; his attempts to investigate Buliminella elegantissima failed, the specimens being too small and too transparent. Structural observations presented in this paper show that some reinterpretation of Höglund's accurate drawings is necessary (Fig. 1).

Hofker (1951), by using a different technique, was able to go beyond the observations of Höglund. His numerous sections allowed him to revise the systematics of the Buliminacea substantially. By comparing the toothplate morphology of different species, he established three new genera, Praebulimina, Praeglobobulimina and the now no longer recognised Protoglobobulimina. Hofker recognised three main types of toothplates; a simple straight plate, as in Praebulimina; a fold, usually with a serrated edge and a cornet-shaped bottom, as in Bulimina trigonalis; and a cornet-shaped trough, with one edge rolled-up onto itself, thus producing a secondary aperture, as in Bulimina marginata (Fig. 2).
Nørvang (1966, 1968) devised a method to reconstruct Foraminifera from serial sections. His observations on Bulimina striata led him at first to support the idea of an accessory aperture, but he later revised his opinion on the subject (Glaçon \& Sigal, 1974; Hansen, personal communication).

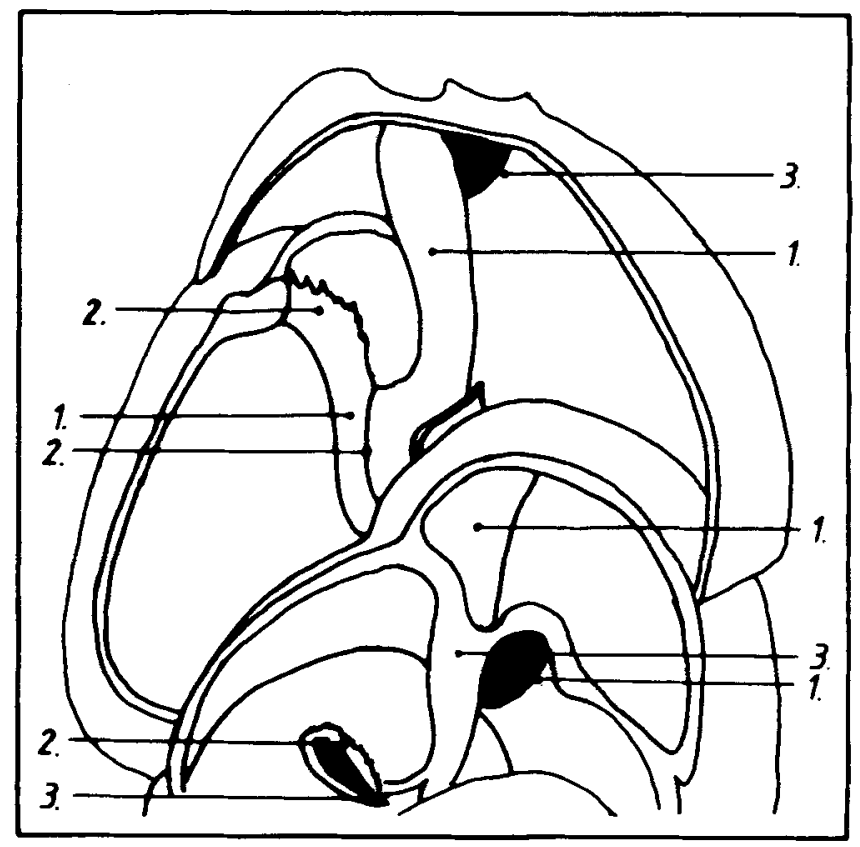

Fig. 1. Schematic drawing by Höglund (1947) of Bulimina marginata, showing the different morphological elements of the apertural complex; 1. Tongue; 2 . Free border of the tongue; 3 . Free border of the aperture. 


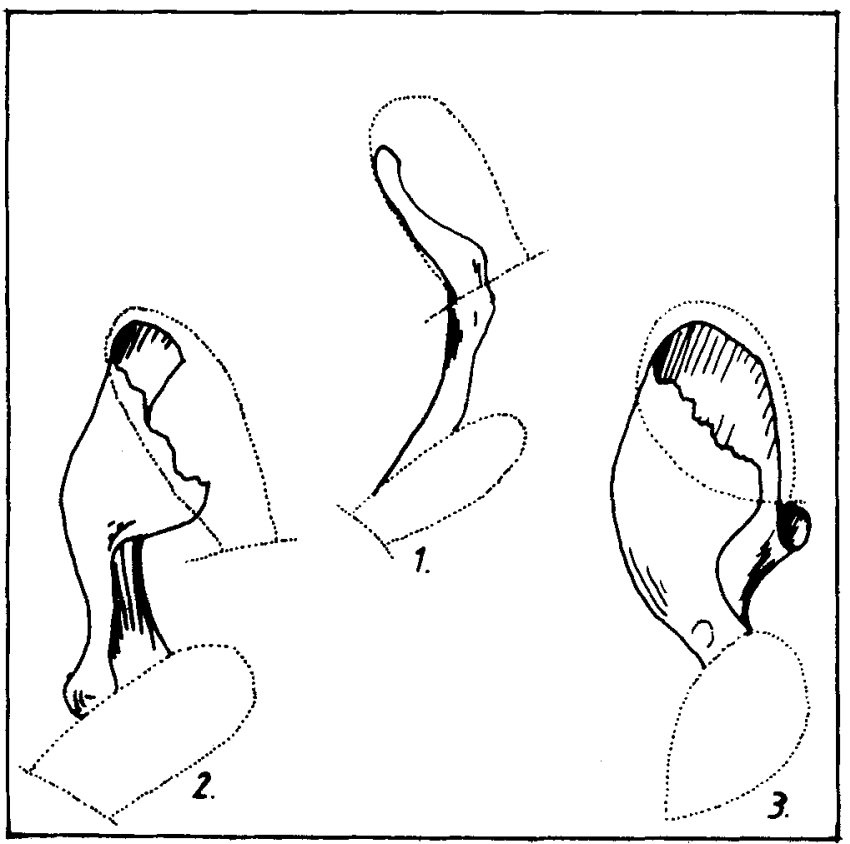

Fig. 2. Schematic drawings by Hofker (1951) of the toothplate of some selected taxa; 1 . Praebulimina sp. 2. Bulimina trigonalis; 3. Bulimina marginata.

Since then, very few studies have been devoted to the taxonomical utility of the anatomy of the toothplate (Haynes, 1954; Glaçon \& Sigal, 1974; Scott, 1977, 1978; Nomura, 1983). The major volumes on foraminiferal systematics have incorporated the work by Höglund and Hofker almost without alteration or emendation (Loeblich \& Tappan, 1964; Haynes, 1981).

This study aims at describing and clarifying the anatomy of the apertural complex in representative genera of the Buliminacea, as a first step towards the revision of the genera studied. The detailed analysis of the apertural complex yields additional characteristics which can be used for taxonomical and phylogenetical purposes.

\section{MATERIALS AND METHODS}

Sections were made by combining the methods of Grønlund \& Hansen (1976) and van Morkhoven (1958). The sectioned specimens were either coated immediately, or first dissolved out of the Lakeside Cement with $96 \%$ ethanol and subsequently coated for SEM observation. Whole and sectioned specimens were observed in the Philips 515 SEM of the Geological Institute of the University of Copenhagen, Denmark. A variety of sections were made for each species, so that the internal morphology could be observed from different angles. At the same time, the representativity could be checked.

The species studied include Bulimina marginata (Milford Sound, New Zealand, Galathea St. 617), Bulimina pagoda (Gulf of Panama, Galathea St. 734), Bulimina trigonalis (Palaeocene, Gelinden, Belgium), Globobulimina auriculata forma arctica (Faskrudfjördur, Iceland), Praeglobobulimina spinescens (Gulf of Panama, Galathea St. 732), Buliminella elegantissima (Laes $\varnothing$, Kattegat, Denmark), Buliminella exilis (Gulf of Panama, Galathea St. 729), Buliminella aff. madagascariensis (Great Australian Bight, Galathea St. 561), Buliminellita mirifica (Miocene, Monterey, California, USA), Buliminoides williamsonianus (Coral Sea, Galathea St. 544), Turrilina andreae (Oligocene, Grundfør, Denmark), and Praebulimina pusilla (Upper Cretaceous, England).

\section{OBSERVATIONS}

The apertural border, i.e. the area immediately adjacent to the opening in the chamber wall, is usually reinforced and thus forms a lip or a modification thereof. In most species, the lip is placed at the peripheral side of the aperture. It quite often continues by curving round at the top of the apertural opening so that a small part of the lip may be present at the axial side of the aperture. The small depression between the

\section{Explanation of Plate 1 \\ The toothplate of Bulimina marginata (Scale bar).}

Fig. 1. An overall view of the toothplate anatomy. Notice the curving in the plate necessary to connect aperture (in the upper right corner) with foramen (the lip of which can be seen in the lower left corner) $(50 \mu \mathrm{m})$.

Fig. 2. Overview of an etched section, showing the toothplates of different chambers $(100 \mu \mathrm{m})$.

Fig. 3. A mosaic picture of the ultimate toothplate of the specimen shown in fig. 2. The lip (1) is bilamellar and descends as such for a short distance into the chamber lumen. The inner lining (i) extends further down until it encounters the foramen (f) which then shows a trilamellar character. Notice that the tip of the toothplate is bilamellar over its entire curved top $(10 \mu \mathrm{m})$.

Fig. 4. A detail of a section through the foraminal lip. The lip is bilamellar (inner lining and outer lamella) but the tip and some part of it at the axial side are covered by a third layer which is the inner lining of the next chamber, i.e. the toothplate. The cavity (c) which is thus formed can here be seen $(10 \mu \mathrm{m})$.

Fig. 5. An etched section showing the form of the aperture in section and the toothplate of the prepenultimate chamber $(100 \mu \mathrm{m})$.

Fig. 6. A close-up of the toothplate of the prepenultimate chamber. The wall going down in the chamber is bilamellar $(w)$ but the toothplate $(t)$ is monolamellar (i) and joined to the outer lamella (o) of the wall. 


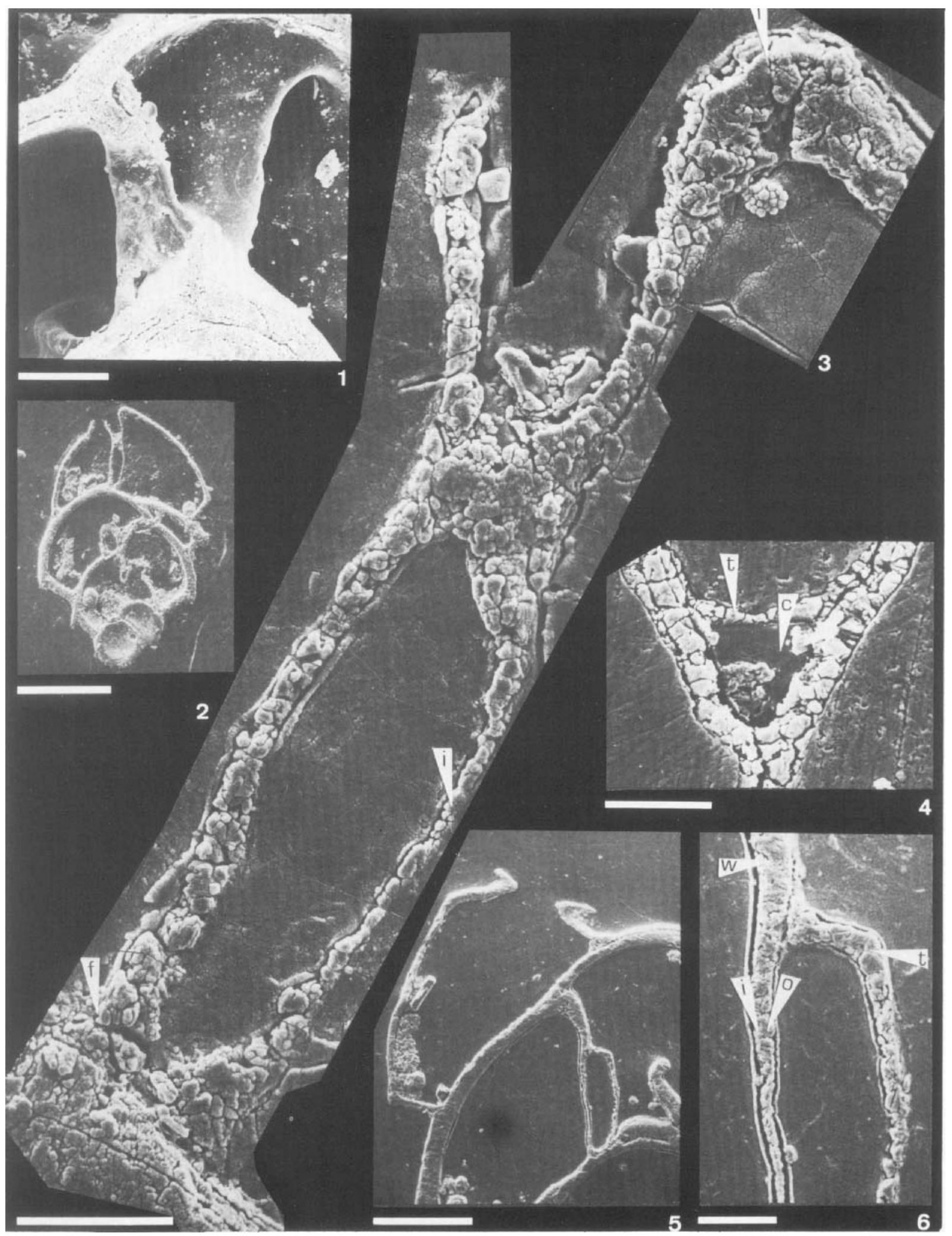


apertural rim on the axial side of the aperture, which usually covers the top of the toothplate, and the raised chamber wall is the sulcus (for clarification of the anatomical terms used in this study, see Fig. 3). The lip may be everted (as in Bulimina marginata or Turrilina andreae, see Pl. 2, fig. 3 and Pl. 4, fig. 7), barely raised above the surface of the chamber wall (as in Praebulimina pusilla, Pl. 5, fig. 9), or entirely internal (as in Praeglobobulimina spinescens, P1. 6, figs. 6, 7). The lip may be modified to a crista (Buliminella exilis, Pl. 4, figs. 2, 3, 4), a tongue (Globobulimina auriculata, Pl. 6, fig. 2), or a cover flap (Buliminella aff. madagascariensis, Pl, 3, fig. 6).

The lip, and a fortiori its modifications, is bilamellar and continuous with the chamber wall (PI. 1, figs. 3, 4; Pl. 3, fig. 4; Pl. 6, figs. 4, 7, 9). Little change takes place when the aperture is converted into a foramen. No septal flap is formed (sensu Hansen \& Lykke Andersen, 1976). A piece of inner lining is drawn-out from under the axial-most part of the aperture into the chamber lumen and attached to the septum, close to the foramen: this is the toothplate (Pl. 1, fig. 1; Pl. 2, figs. 5, 7; Pl. 3, figs. 7, 8; Pl. 4, figs. 4, 8; Pl. 5, fig. 2; Pl. 6 , figs. 8,9 ). At least one edge of this plate leaves the chamber wall, becoming the free border. This border commonly curves towards the attached border, touching it somewhere on its way down, thus forming a closed funnel. Usually, the toothplate butts into the axial-most part of the foramen, ending blindly in the sulcus (Pl. 2, fig. 2; Pl. 4, fig. 3; Pl. 5, fig. 2). In some cases, the toothplate continues over to the peripheral part of the foramen, where it then covers the foraminal lip, or its modifications, with an extra layer of inner lining; this however is not to be confused with a septal flap (Pl. 2, fig. 2; Pl. 4, fig. 5). The site of attachment remains restricted to the sulcus and the adjacent region; it does not extend over the septum nor onto the

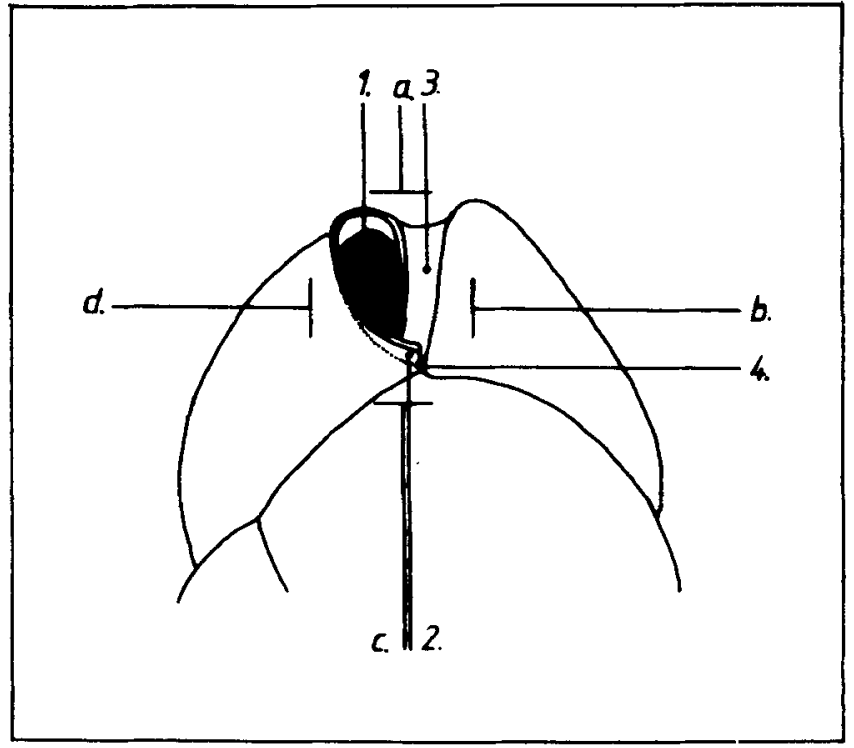

Fig. 3. Schematic drawing explaining the anatomical terms used; 1. Apertural opening; 2. Apertural lip; 3. Sulcus; 4. Umbilicus. Direction relative to the apertural opening; a. top-most; b. axial side; c. bottom-most; d. peripheral side.

toothplate of the foramen. Earlier toothplates remain monolamellar (Pl. 1, figs. 5, 6; Pl. 6, fig. 9).

\section{ANATOMY IN DIFFERENT GENERA}

In Bulimina, a number of different toothplate morphologies exist. The simplest toothplate can be found in primitive species, such as Bulimina trigonalis. The lip is fairly massive and well rounded, sometimes sparsely cristate (Pl. 2, fig. 6). At the top, it curves round the apertural opening and across the border to form the top of the toothplate. The toothplate itself is rather simple; it is a plate, attached for about half its length. The lower-most half becomes free, rolls-up to a

\section{Explanation of Plate 2 \\ Bulimina marginata.}

Fig. 1. Overall morphology $(100 \mu \mathrm{m})$.

Fig. 2. A partially etched section of the penultimate foramen. The periapertural lip of the foramen (fl) is virtually identical with the ultimate lip but for the toothplate ( $t$ ) which has butted into the umbilical-most part of the foramen. Notice that this bottom-most part of the toothplate is entirely closed off since it has joined itself to the chamber wall of the previous chamber (pw). The very bottom of this cavity is the wall of the previous chamber $(20 \mu \mathrm{m})$.

Fig. 3. The aperture showing the periapertural lip curving round the aperture and descending into the lumen. Compare this with the previous figure $(20 \mu \mathrm{m})$.

Fig. 4. Overall morphology $(100 \mu \mathrm{m})$.

\section{Bulimina pagoda.}

Fig. 5. The morphology of the toothplate of the ultimate chamber. Note the form of the plate which is only partially attached to the foramen, thus leaving a large gap $(\mathrm{g})(20 \mu \mathrm{m})$.

Fig. 6. Overall morphology $(100 \mu \mathrm{m})$.

\section{Bulimina trigonalis.}

Fig. 7. Section showing the primitive toothplate $(10 \mu \mathrm{m})$. 


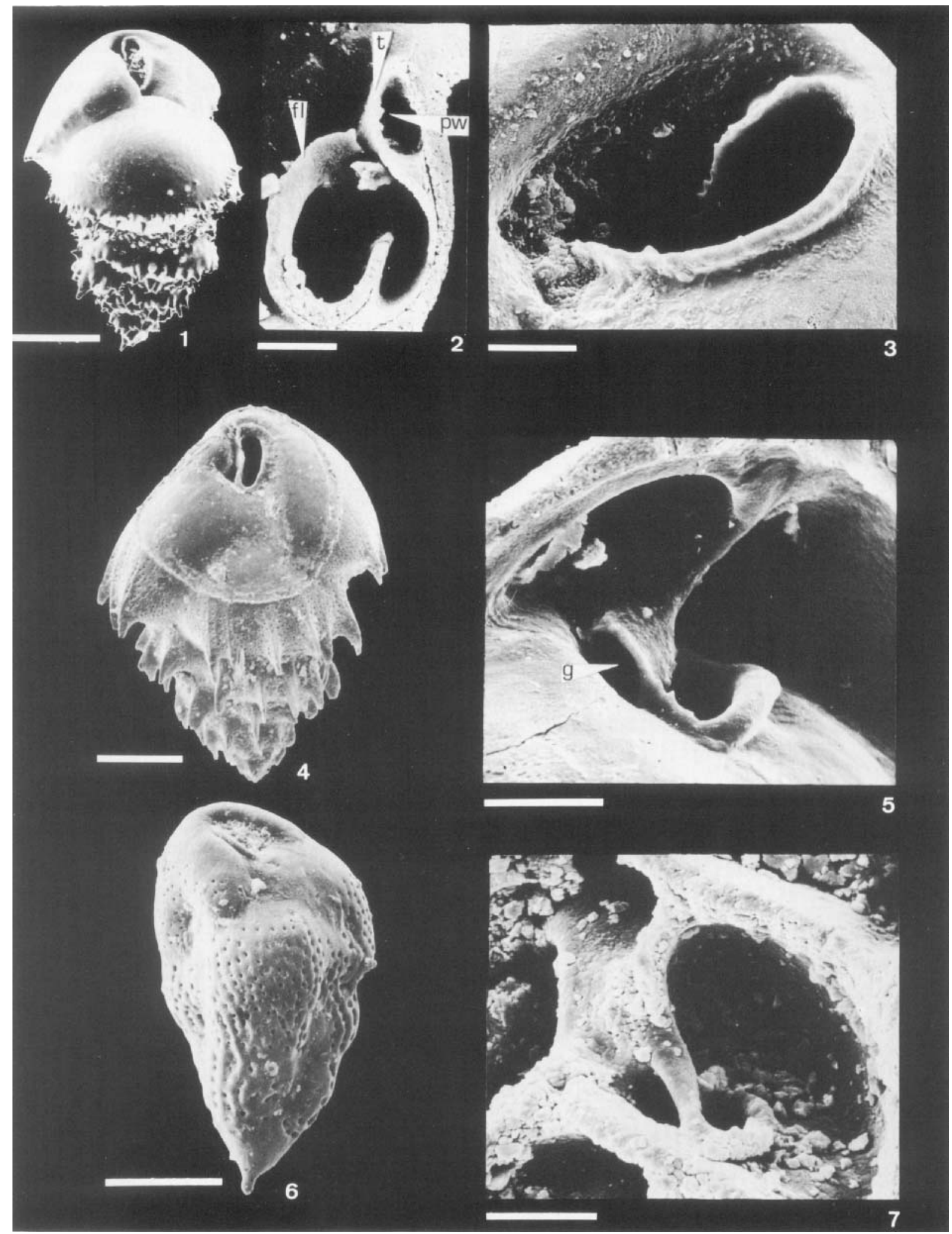


lesser extent and attaches itself to the foraminal lip, close to the umbilicus where it stretches for only a short distance (Pl. 2, fig. 7).

The apertural morphology of Bulimina marginata is somewhat different. The lip surrounding the aperture is more slender, more everted and usually more distinctly cristate (Pl. 2, figs. 2, 3). It also curves round at the top of the aperture and covers the top of the toothplate. The toothplate is massive and straight, one flange remaining attached to the chamber wall. The free border curves round towards the attached flange, until it actually touches this flange. The tube thus formed butts into the foramen at the axial, umbilical side. where the attachment site is fairly short (Pl. 1, fig. 1; Pl. 2, fig. 2). The foraminal lip is partly covered by the toothplate as its seals itself to the foraminal face. In some specimens this leads to the formation of a blind cavity, adjacent to the foramen. As the toothplate approaches the foraminal lip, it hovers above the foraminal sulcus; when the toothplate actually makes contact with the lip, a cavity is produced by the overhanging of the sulcus by the toothplate ( $\mathrm{Pl}$. 1, fig. 4).

In Bulimina pagoda, this cavity is not formed. The foraminal lip is everted to such an extent that the bridging of the sulcus by the toothplate fails to reach the chamber wall, thus leaving a large gap. The toothplate fuses with the foraminal lip at the axial side, over quite a large distance (Pl. 2, fig. 5).

Buliminella can be split into three different groups. In Buliminella elegantissima, the aperture lies in the upper fourth of a long apertural face. The apertural opening is entirely surrounded by a sparsely cristate and distinctly everted lip, which is bilamellar over its entire length ( $\mathrm{Pl} .3$, figs. 2, 4, 5). Inside the chamber lumen, no structures are present (Pl. 3, figs. 3, 4, 5).

Buliminella exilis differs substantially from B. elegantissima. The aperture, sitting in, for a buliminid, a normal apertural face, is flanked by a modified lip. The lip is modified to such an extent that it seems appropriate to give it a name of its own: a crista. The crista encircles the aperture at the peripheral side only, since the axial side of the apertural opening is delimited by the presence of the penultimate chamber (PI. 4, fig. 2 ). Thus, a sulcus cannot be present. The number of teeth on the crista increases during ontogeny. The toothplate is drawn out from under the top-most part of the apertural wall. It descends into the chamber lumen, at first as a curved plate with one attached border. As it descends deeper into the lumen, the fixed flange gradually breaks away from the chamber wall until it becomes free. It continues to curve towards the free border, but before contact is made, both flanges meet the chamber wall, forming a gutter-like tube (PI. 4, figs. $3,4)$. This tube butts into the foramen at its axial, top-most part, i.e. in the area between the foraminal crista, the wall of the ultimate chamber and the wall of the prepenultimate chamber, where it ends blindly ( $\mathrm{Pl}$. 4, fig. 3).

Buliminella aff. madagascariensis has a semi-circular apertural face, ploughed by grooves, radiating away from the aperture itself. This aperture is hidden by a cover-flap, which is formed by an extension of the chamber wall from the basal peripheral part of the apertural face (Pl. 3, fig. 6). Inside the chambers, the characteristic morphology of B. exilis is present (Pl. 3, figs. 7,8 ).

The final aperture of Buliminellita mirifica is produced on a neck. It differs from the characteristic $U$ vigerina neck in that no everted rim is present (Pl. 5, figs. 1,3). Sections show that a toothplate is present throughout the ontogeny. Earlier chambers show the typical B. exilis morphology, external as well as internal (Pl. 5, fig. 2). The ultimate chamber is substantially smaller and strongly twisted; nevertheless, a toothplate is present (Pl. 5, fig. 3).

Buliminoides williamsonianus does not possess a clear and definite aperture. In some specimens, a large hole is present at the apex of the test, but these specimens have an empty interior; all internal calcite has been resorbed, probably for reproductive purposes (PI. 5, fig. 5). Other specimens have an apex bearing the triangular ends of the heavy costae, which run along the entire test length. Under some of these triangular

\section{Explanation of Plate 3 \\ Buliminella elegantissima.}

Fig. 1. Overall morphology $(100 \mu \mathrm{m})$.

Fig. 2. A close-up showing that the periapertural lip is closed onto itself $(10 \mu \mathrm{m})$.

Fig. 3. A close-up of the prepenultimate foramen $(10 \mu \mathrm{m})$.

Fig. 4. An etched section showing successive foramina (f) but without connection between them $(20 \mu \mathrm{m})$.

Fig. 5. An internal view of the penultimate foramen showing the origin of the periapertural lip and the absence of internal structures $(10 \mu \mathrm{m})$.

Fig. 6. Overall morphology $(100 \mu \mathrm{m})$.

Fig. 7. A section showing the succession of toothplates ( $t)(100 \mu \mathrm{m})$.

Fig. 8. A close-up of a foramen showing the toothplate ( $\mathrm{t}$ ), the foramen (f) and the foraminal lip (fl) $(10 \mu \mathrm{m})$. 

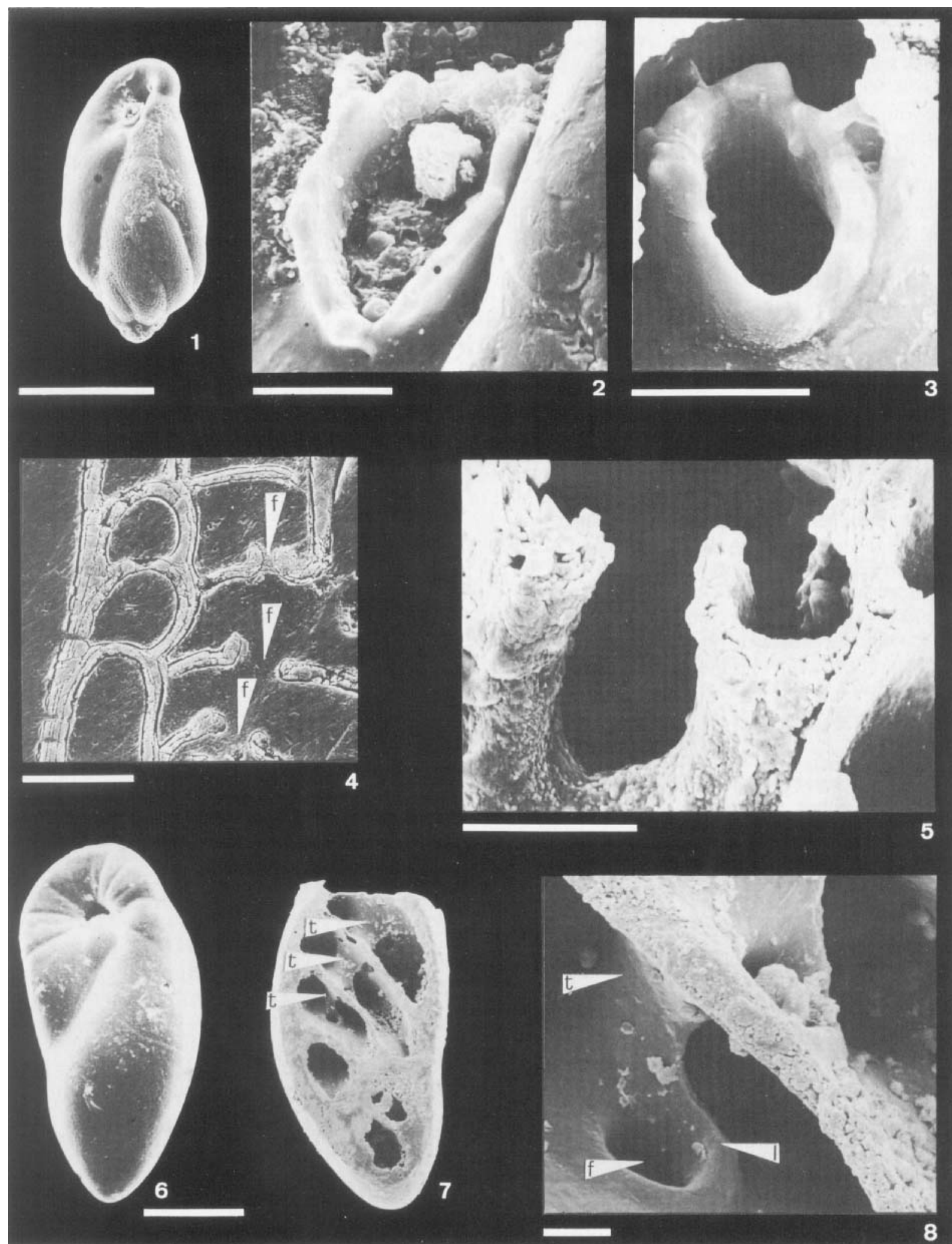
ends, small openings can be seen, presumably the apertures ( $\mathrm{Pl} .5$, figs. 4, 7). The lumines are surprisingly small and the wall between them very thick. It seems that the toothplate is absent, but this is difficult to judge, since foramina are not recognisable (P1. 5, fig. 6).

The aperture of Globobulimina auriculata forma arctica is a large semicircular opening at the apex of the chamber. This opening continues downwards to the basal suture, which separates ultimate from penultimate chamber. In the apertural opening a large and prominent tongue sticks out. This spoon-like protrusion is usually attached to the chamber wall at both sides of the aperture (Pl. 6, figs. 1, 2). Inside the chamber lumen, this tongue continues as a subapertural arch on the axial side of the aperture. This arch fuses with the foraminal tongue, without covering it; a suture is clearly visible (Pl. 6, fig. 3). From a structural point of view, the toothplate is absent. In the whole foraminal complex, not one element is monolamellar (Pl. 6, fig. 4).

Praebulimina pusilla possesses a stellate, triangular aperture, instead of the more common loop-shaped or virgular one. The aperture is partly circumscribed by a low, smooth lip. At the top-most part of the aperture, it moves over the border and seems to descend into the lumen. A sulcus is not present (Pl. 5, frgs. 8, 9). Inside the chamber a thickening is seen to run from the aperture towards the foramen: the toothplate. Transverse sections show that the toothplate fuses with the foramen over quite some length at the axial side of the foramen (P1. 5, fig. 10).

The aperture of Praeglobobulimina spinescens is a narrow, elongate slit, starting at a basal suture and running straight up, somewhat surpassing the apex of the chamber. A closely serrated 'tooth' can be seen sitting in the middle of the apertural slit. Sections show this to be the edge of a gutter-like infolding of the chamber wall, adjacent to the aperture. This bilamellar feature blocks half of the narrow aperture (Pl. 6, figs. 6, 7). The toothplate starts from under the 'tooth' and runs down until it encounters the foraminal 'tooth'. The plate is fairly thin, gently curved and it remains attached for about one third of its length. It does not form a funnel or tube at its base (Pl. 6, figs. 8, 9).

Turrilina andreae possesses a distinct, everted lip which surrounds the aperture but for its top-most part. Here the lip descends for a short distance into the chamber lumen, forming a seam on the toothplate (PI. 4, fig. 7). The toothplate starts as a plate, the edges tending towards each other while descending into the lumen, forming a concave trough. The toothplate butts into the foraminal face at the axial-most part of the foramen, where it fuses, sitting partially over the foraminal lip (Pl. 4, fig. 8).

\section{DISCUSSION}

It has now become possible, after structural observations, to describe the different elements of the apertural complex. Structurally speaking, two elements are present: the monolamellar toothplate, and the bilamellar chamber wall with all its everted modifications. Most authors considered the toothplate as a structure originating from the foramen and making contact with the aperture (Glaessner, 1954; Nomura, 1983; Scott, 1978), or as a structure continuous either with the apertural face (Hofker, 1951), or with the outer chamber wall (Belford, 1966). Actually, as demonstrated herein, the toothplate is a continuation of the inner lining underlying the apertural face, and this plate fuses with the outer lamella of the foramen, since no septal flap (sensu Hansen \& Lykke Andersen, 1976) is present. A number of consequences follow because the toothplate is formed from the inner lining: it is imperforate and does not receive secondary lamination; since there is no septal flap, it cannot be covered by the inner lining and thus not by the toothplate of the next chamber; since it is topologically speaking 'inside', it cannot come into contact with the outside world.

\section{Explanation of Plate 4 \\ Buliminella exilis.}

Fig. 1. Overall morphology $(100 \mu \mathrm{m})$.

Fig. 2. A close-up of the aperture showing the crista encircling the aperture. Note that the crista is not encircling the entire aperture: it is delimited at the axial side by the raised wall of the chamber, as is the aperture $(10 \mu \mathrm{m})$.

Fig: 3. A view of the foramen with the crista (c) and the toothplate wedged-in (t). Note that the bottom of the toothplate is the chamber wall and that the toothplate is not entirely closed $(10 \mu \mathrm{m})$.

Fig. 4. A view of the internal morphology with the foraminal crista (c), the chamber wall of the next chamber (w) and its toothplate $(\mathrm{t})(20 \mu \mathrm{m})$.

Fig. 5. A detail of fig. 3 showing the jointure of the toothplate to the chamber wall. Note that the toothplate (t) is fixed to the bilamellar chamber wall $(w)(2 \mu \mathrm{m})$.

\section{Turrilina andreae.}

Fig. 6. Overall morphology $(100 \mu \mathrm{m})$.

Fig. 7. The aperture with the everted periapertural lip which at its umbilical-most part descends into the lumen, leaving a gap $(\mathrm{g})(10 \mu \mathrm{m})$.

Fig. 8. The internal morphology showing the toothplate (t) joining the foramen (f) $(10 \mu \mathrm{m})$. 

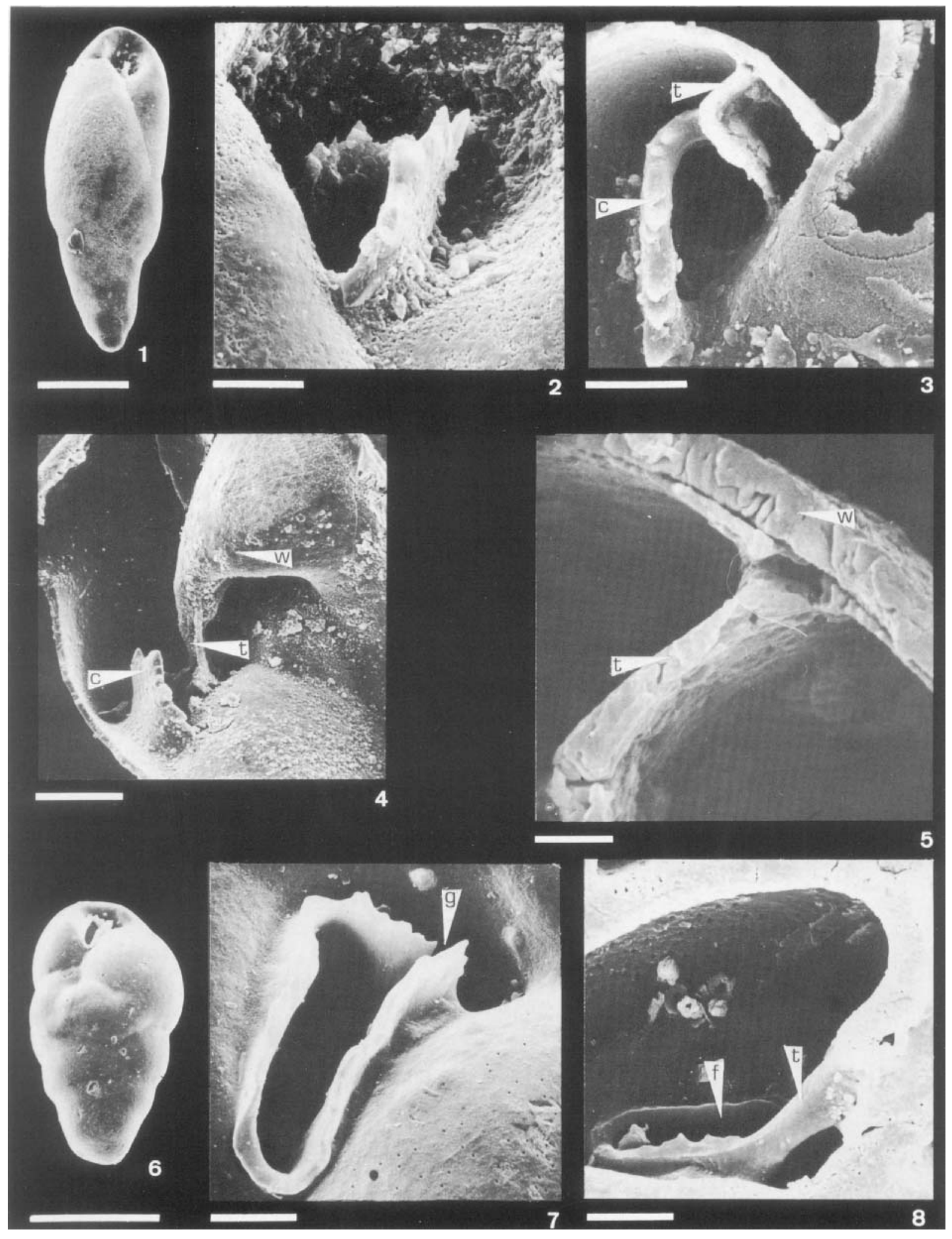
These restrictions, being generally valid (see for example Hansen \& Lykke Andersen, 1976), do not allow the existence of the secondary foramen and tube as postulated by Hofker (1951).

In the more advanced species of Bulimina, Hofker described the free border as being rolled-up, thus forming a tube, the superior opening of which was supposed to be positioned at the peripheral side of the aperture, just below the plane of the apertural face, where it ended as a secondary foramen. His observations on sections in the light microscope led him to believe that these tubes were connected to each other so that in the earlier chambers no other openings were present but the foramen. This argumentation was originally followed by Nørvang (1966), but his superior technique led him eventually to abandon the idea of a tube. Recently, some authors have tried to reinstate Hofker's view (Haynes, 1981; Verhallen, 1986). As shown here, this 'Hofker' anatomy is not allowed by the general principles of foraminiferal architecture, and it actually does not exist. Not only is it impossible to find a tube; the structural observations on the toothplate during ontogeny exclude the possibility of it being overlooked. If this tube were to exist, it should be perforate, bilamellar and should receive secondary lamination during ontogeny. The illustrations presented in this study clearly show that this is not the case. There is no passage between the successive chambers but for the foramen. It appears that the absence of a secondary aperture is consistent throughout the Buliminida: in other taxa with a toothplate, there is no resorption of the chamber wall adjacent to the aperture, leading to the existence of a supplementary opening (see also Scott, 1977).

It transpires from the literature that a number of misconceptions about the apertural elements still circulate. The two typical cases are the confusion between the toothplate proper and the various modifications of the lip, and the nature of the modification of the lip. Many authors (Hofker, 1951; Loeblich \& Tappan, 1964; and since then most authors) seem to think that the spoon of Globobulimina and the periapertural lip in Buliminella elegantissima is the toothplate. This is not the case, as demonstrated earlier. The lip, under whatever form, is a morphological element continuous with the entire chamber wall. Another example is the description of Praeglobobulimina by Haynes (1981) where it is stated that 'the tip of the toothplate protrudes as a cockscomb'. From Plate 6 it appears that this 'cockscomb' is in fact the lip, albeit strongly modified.

These results carry some important taxonomical implications. In the past, some authors have suggested that it should be possible to subdivide Bulimina into a number of subgenera (Hofker, 1951; Haynes, 1954). It seems that a comparative study of the toothplate morphology, in conjunction with external characteristics, could allow the recognition of subgeneric taxa. Preliminary results indicate some interesting prospects, especially since some of the very early Bulimina's (e.g. Bulimina arkadelphiana) show fairly advanced morphological characteristics.

Contrary to the opinion of Papp \& Schmidt (1985), Praeglobobulimina is considered valid and different from Globobulimina. The position of the apertural lip, i.e. in the apertural opening causing the sulcus to be at the 'wrong' side, i.e. on the umbilical side instead of on the axial side, and the peculiar toothplate are more than sufficient grounds to merit generic status.

Although Globobulimina does not possess a toothplate, it is preferable to retain the genus in the Buliminacea. The absence of a toothplate appears to be due to secondary loss. More in particular, since the apertural lip has been modified to such an extent that it bridges the distance between the aperture and the foramen, there is no space left for a toothplate.

Fig. 1. Overall morphology $(100 \mu \mathrm{m})$.

\section{Explanation of Plate 5 \\ Buliminellita mirifica.}

Fig. 2. Internal morphology of the earlier chambers showing crista (c) and toothplate (t) $(10 \mu \mathrm{m})$.

Fig. 3. Internal morphology of the ultimate chamber where, despite the different chamber form a toothplate $(t)$ is stil present $(20 \mu \mathrm{m})$.

\section{Buliminoides williamsonianus.}

Fig. 4. Overall morphology of a normal specimen $(100 \mu \mathrm{m})$.

Fig. 5. Overall morphology of a specimen which has undergone reproduction, i.e. it has been hollowed out as can be seen by the presence of a hole instead of the normal apex of the test $(100 \mu \mathrm{m})$.

Fig. 6. A section through a normal specimen showing the very thick walls and apparent lack of internal structures $(100 \mu \mathrm{m})$.

Fig. 7. The apex of a normal specimen showing some minor openings (o) which probably form the aperture $(20 \mu \mathrm{m})$.

Fig. 8. Overall morphology $(100 \mu \mathrm{m})$.

\section{Praebulimina pusilla.}

Fig. 9. The stellate aperture with the simple thick lip curving inwards $(20 \mu \mathrm{m})$.

Fig. 10. A section showing the foramen and the lower-most part of the straight toothplate $(20 \mu \mathrm{m})$. 


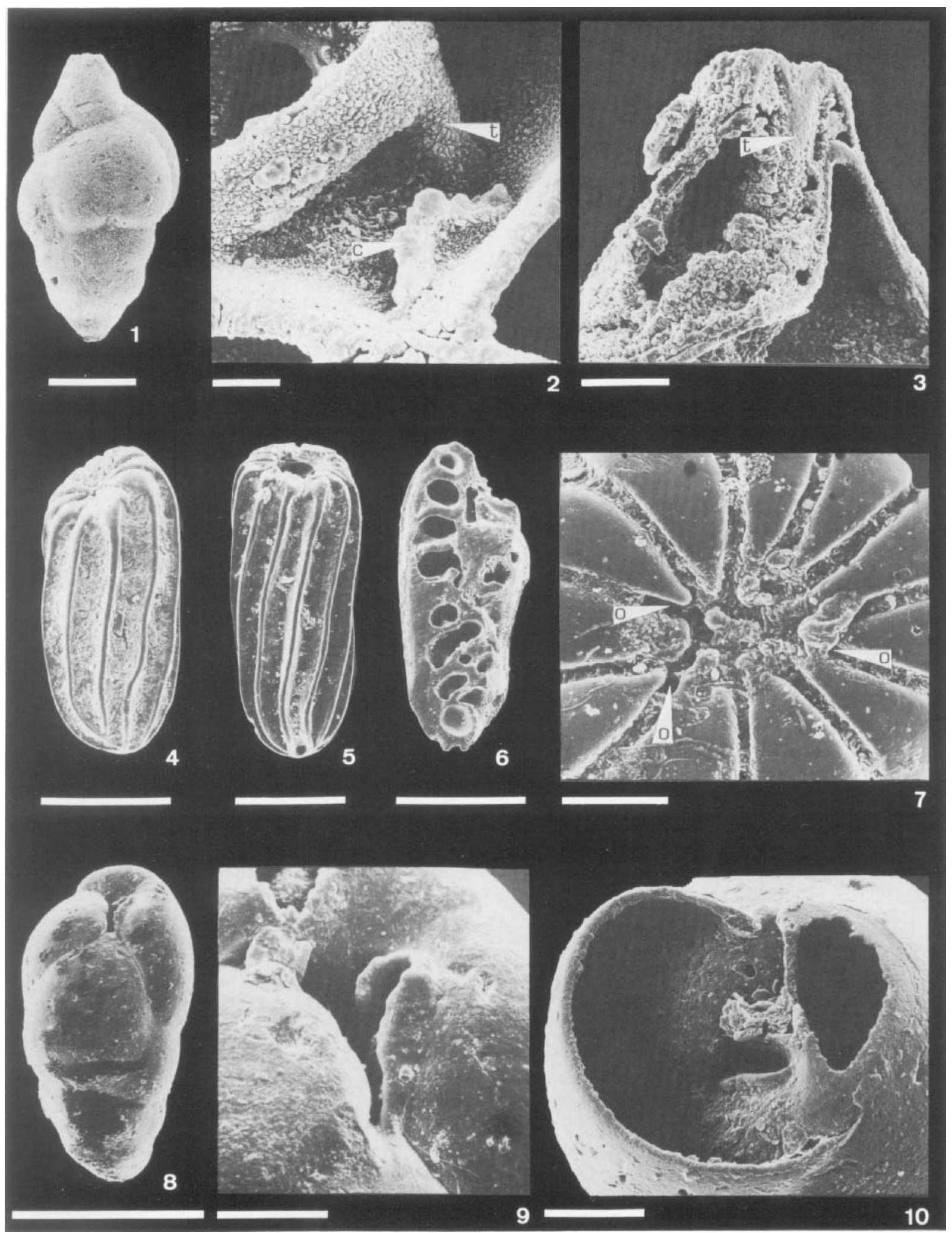


Substantial revisionary work is to be carried out on Buliminella. The type species, $B$. elegantissima does not belong in the Buliminacea. It has no internal structure whatsoever, the lip is different from all other buliminids, and its habitus is also quite unique. Besides a small number of species close to $B$. elegantissima another group of Buliminella species needs to be investigated more closely. This group is distinguished by possessing an apertural flap, which covers the aperture of the ultimate chamber. For these species a reappraisal is also needed, especially so if one is to retain Buliminellita as a separate genus. Buliminellita mirifica is indistinguishable from the remaining Buliminella species apart from its ultimate chamber. A revisional study to clarify many of the problems raised is currently underway.

Buliminoides is a genus which continues to pose serious problems. Loeblich \& Tappan (1984) placed Buliminoides in the Glabratellacea because of its plastogamic reproduction. At the present state of knowledge, this proposal cannot be supported for a number of reasons: plastogamic reproduction, and indeed any form of reproduction, has been documented for extremely few species; it seems inadvisable to delineate taxa on the basis of virtually non-investigated characteristics; furthermore, the apertural characteristics of Buliminoides and Glabratella are radically different, and so is their general habitus. Since it has proved to be impossible to find internal morphological traits and since the aperture is quite aberrant, it is proposed to consider Buliminoides as incertae familiae, for the time being. A revisional study is in progress, but it is still too early to venture any proposal.

\section{CONCLUSIONS}

Structural observations define the toothplate as a piece of inner lining running from the interior side of the aperture to the foramen. The lip and other modifications which are part of the apertural complex are bilamellar and thus of a different nature than the toothplate.

This complex of characteristics carries the promise of taxonomical utility and it makes the need for revisions more acutely felt. Phylogenetic speculations will not carry fruit before thorough descriptions become available and consequently new insights are gained.

\section{ACKNOWLEDGEMENTS}

I wish to thank H. J. Hansen and J. F. Nielsen of the Geological Institute of the University of Copenhagen, Denmark, for the hospitality, creative environment and access to the SEM. Part of the results presented were obtained during a scholarship at the Geological Institute of the University of Copenhagen, granted by the Belgian-Danish Cultural Agreement.

Fig. 1. Overall morphology $(500 \mu \mathrm{m})$.

Fig. 2. The aperture with the spoon-like protrusion. Note the presence of two openings due to the contact of the 'spoon' with the apertural border $(50 \mu \mathrm{m})$.

Fig. 3. The internal morphology with the foraminal 'spoon' (s) and the subapertural arch (sa) separated by a clear suture (st). Note that the subapertural arch possesses pores (p) $(50 \mu \mathrm{m})$.

Fig. 4. An etched section through a foramen showing the thickening of the foraminal border (b), the subforaminal arch (sa), the 'spoon' (s), and the subapertural arch i.e. the one belonging to the next chamber (saa). Note that all these elements are bilamellar $(20 \mu \mathrm{m})$.

Fig. 5. Overall morphology $(100 \mu \mathrm{m})$.

\section{Praeglobobulimina spinescens.}

Fig. 6. The aperture with the 'cockscomb'. Note at the base of the aperture the gutter between 'cockscomb' and apertural border $(20 \mu \mathrm{m})$.

Fig. 7. An etched section through the aperture showing the 'cockscomb' to be a continuation of the chamber wall $(w)$. The peculiar curving round of the apertural wall creates a gutter $(\mathrm{g})$ which runs along the entire length of the aperture $(10 \mu \mathrm{m})$.

Fig. 8. A view of the internal morphology with the different toothplates $(\mathrm{t})$, the foraminal borders, and 'cockscombs' (c). Note that the toothplate originates from under the 'cockscomb' and that it fuses at its bottom with the tip of the previous 'cockscomb' $(50 \mu \mathrm{m})$.

Fig. 9. An etched section through a foramen with the peripheral foraminal border ( $\mathrm{fb}$ ), the tip of the foraminal 'cockscomb' (c) and the toothplate ( $t$ ) descending from the next aperture. Note that only the toothplate is monolamellar $(10 \mu \mathrm{m})$. 


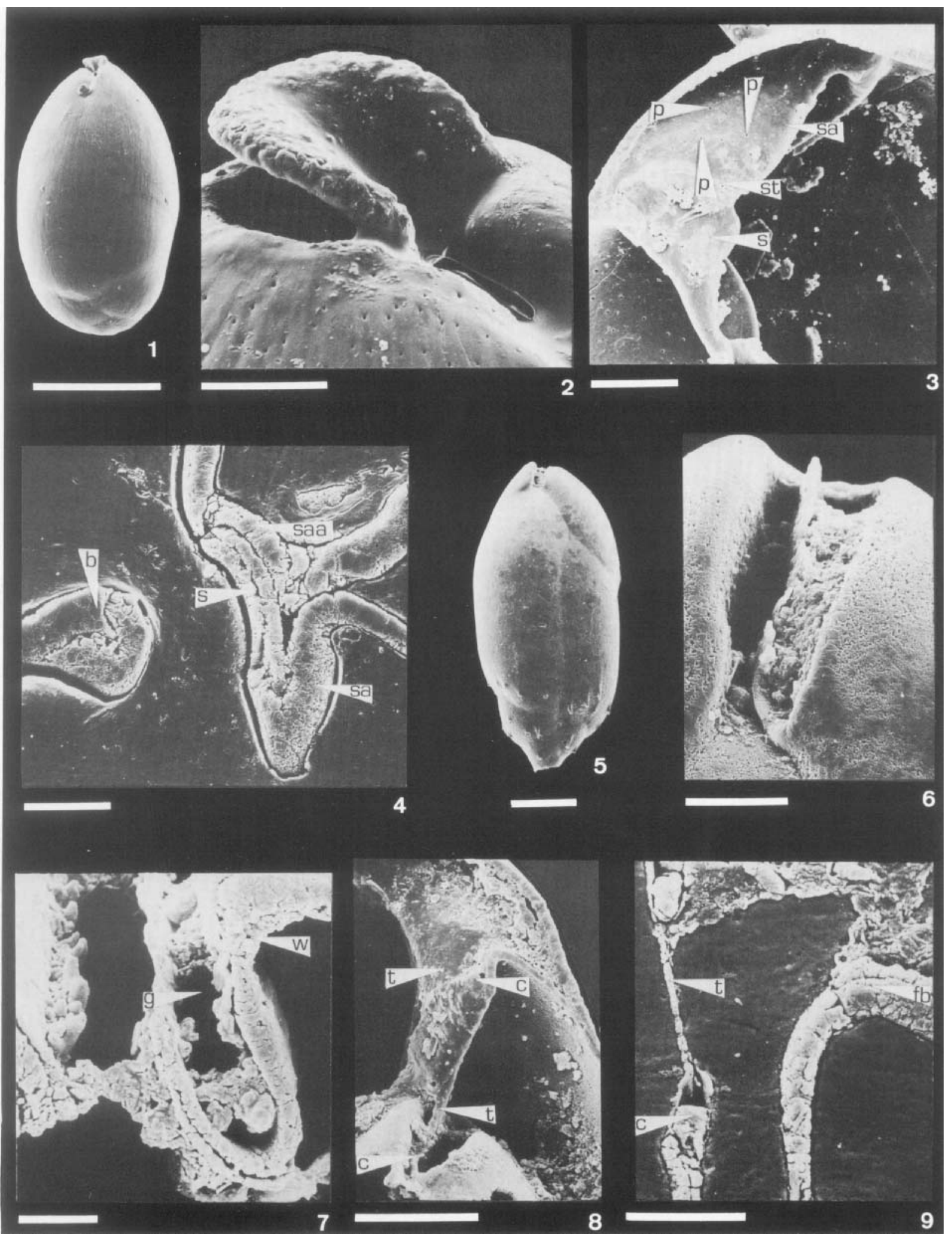




\section{REFERENCES}

Belford, D. J. 1966. Miocene and Pliocene Smaller Foraminifera from Papua and New Guinea. Bull. Australia Bur. Min. Res. Geol. Geophys., 79, iv $+306 \mathrm{p}$.

Glaçon, G., and Sigal, J. 1974. Morphologie de l'appendice buccal chez Caucasina (Foraminifère), suivie d'une comparaison avec celui de divers genres de Buliminidae. Revta Esp. Micropaleont., 6, 209-227.

Glaessner, M. F. 1954. New Aspects of Foraminiferal Morphology and Taxonomy. Contr. Cushman Fdn Foramin. Res., 5, 21-25.

Grønlund, H., and Hansen. H. J. 1976. Scanning Electron Microscopy of some Recent and Fossil Nodosariid Foraminifera. Bull. Geol. Soc. Denmark, 25, 121-134.

Hansen, H. J., and Lykke Andersen, A. 1976. Wall Structure and Classification of Fossil and Recent Elphidiid and Nonionid Foraminifera. Fossils and Strata, 10, 1-37, 22 pls.

Haynes, J. 1954. Taxonomic Position of some British Palaeocene Bulimindea. Contr. Cushman Fdn Foramin. Res., 5, 185-191.

Haynes, J. 1981. Foraminifera. McMillan Publishers, London, $433 \mathrm{p}$.

Hofker, J. 1951. The Foraminifera of the Siboga Expedition. Part III. Ordo Dentata, subordines Protoforaminata, Biforaminata, Deuteroforaminata. Uitk. Zool., Bot., Oceanogr. Geol. Geb., monogr. IVa, pp. 1-513.

Höglund, H. 1947. Foraminifera in the Gullmar Fjord and the Skagerak. Zool. Bidr. Upps., 26, 1-328.

Loeblich, A. R. \& Tappan, H. 1964. Sarcodina, chiefly "Thecamoebians" and Foraminiferida, in Moore, R.C. (ed.) Treatise on Invertebrate Paleontology. Geological Society of America and University of Kansas Press, New York and Lawrence. KS, Part C, Protista (2), 2 v., 900 p.
Loeblich, A. R. \& Tappan, H. 1984. Suprageneric Classification of the Foraminiferida (Protozoa). Micropaleontology, 30, $1-70$.

Nomura, R. 1983. Cassidulinacea (Foraminiferida) from the Uppermost Cenozoic of Japan (Part I). Sci. Rep. Tohoku Univ., Ser. 2 (Geol.), 53, 1-101.

Nørvang, A. 1966. The Internal Tooth of Bulimina striata d'Orbigny (Foraminifera), a preliminary notice. Vidensk, Medd. Dansk Naturh. Foren., 129, 285-286.

Nørvang, A. 1968. Interior Characters of Bulimina (Foraminifera). Proceed. I.P.U., XXIII Intern. Geol. Congress, $415-422$.

Papp, A., and Schmidt, M. E. 1985. Die Fossilen Foraminiferen des Tertiären Beckens von Wien: Revision der Monographie von Alcide d'Orbigny (1846). Abh. Geol. Bundesanst., 37, 1-311.

Scott, G. H. 1977. Toothplate cavity in Bolivinita. Revta Esp. Micropaleont., 9, 337-341.

Scott, G. H. 1978. Shell design in Bolivinita quadrilatera, $B$. pohana and B. compressa (Foraminiferida). N. Z. Jl Geol. Geophys, 21, 85-95.

van Morkhoven, F.C.P.M. 1958. A Simplified Method of Grinding Foraminifera. Micropaleontology, 4, 209-210.

Verhallen, P. 1986. Morphology and function of the internal structures of non-costate Bulimina. Proc. K. Ned. Akad. Wet., Ser. B, 89, 367-385. 